\title{
Ayurvedic management of Udavartini Yonivyapad (Ovarian Endometrioma)- A Case Report
}

\author{
H.L.M. G Sajeewani ${ }^{1}$, M.S. Sajeewane Perera $^{2}$ \\ ${ }^{1}$ Consultant, Head of the Unit of Stree Roga and Prasuti Tantra, Bandaranayake Memorial \\ Ayurveda Research Institute, Navinna, Sri - Lanka. \\ ${ }^{2}$ M.S (Ayu) Post Training Medical Officer, Specialty Stree Roga and Prasuti Tantra, \\ Bandaranayake Memorial Ayurveda Research Institute, Navinna, Sri - Lanka.
}

\begin{abstract}
:
Endometriosis presents in three different entities, which are frequently found together: peritoneal lesions, deep endometriosis and ovarian endometriotic cysts (endometriomas). Endometriosis can be discussed as a syndrome complex of Udavartini Yonivyapad in Ayurveda. A 32-year-old unmarried woman consulted the BMARI hospital with a chief complaint of sever lower abdominal pain, severe menstrual pain and prolong bleeding for 5 years' duration. Patient reported surgical history of laparoscopic cystectomy in right side endometrioma (chocolate cyst) on 2017. Laboratory tests were unremarkable except that the Tumor marker. CA -125 value- 41.1U/ML. Ultrasound revealed (TAS) bulky uterus with adenomyosis. The endometrioma were seen which were thin walled with diffuse homogeneous ground-glass echoes contents measuring around of $3.72 \mathrm{~cm} \times 1.84 \mathrm{~cm}$ in size in the right ovary and $3.09 \mathrm{~cm} \times 2.22 \mathrm{~cm}$ in left ovary; in addition, highly echogenic peritoneal fluid in the cul-de-sac and a pre-ovulatory follicle in the left ovary were observed. After 10 weeks' treatment proceeds patient was recovered completely from pain lower abdomen, Menstrual cycle was regular and at normal intervals without any complications. After treatment CA-125 tumour marker value - 16 U/ML \& USG revealed normal findings with right ovary and left ovary cyst reduced and size to be $1.45 \mathrm{~cm} \times 1.68 \mathrm{~cm}$. Hence it is concluded that above treatment protocol is effective in the management of Udavartini Yoni Vyapad with Kaphajagranthi (Endometriosis with Ovarian Endometrioma).
\end{abstract}

Key words: Endometriosis, Vyadhisankara, Udavartani Yonivyapad

Received: 03.10.2020

Quick Response code

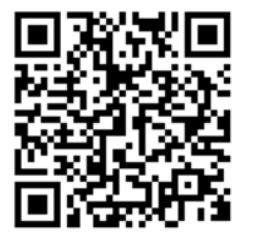

Revised: 15.12 .2020

Accepted: 22.12 .2020 


\section{Introduction:}

Endometriosis presents in three different entities, which are frequently found together: peritoneal lesions, deep endometriosis and ovarian endometriotic cysts (endometriomas). ${ }^{[1]}$. Ovarian endometrioma is a benign estrogen dependent cystic mass arising from ectopic endometrial tissue within the ovary. It contains thick, brown, tar like fluid, which may be referred to as a chocolate cyst. The pathogenesis of endometriomas remains contentious, with a variety of theories proffered, including invagination and subsequent collection of menstrual debris from endometriotic implants, which are located on the ovarian surface and adherent peritoneum. ${ }^{[2]}$

There are nine different types of Granthi have been mentioned in Ayurveda classics depending upon the pathological factor and the body tissue involved ${ }^{[3][4]}$ Granthi is explained as when Rakta (blood), Mamsa (fleshy/muscles), and Meda (fat/adipose tissue) are vitiated by Tridosha that are admixed with Kapha produce rounded glandular, protuberant, knotty and firm swelling. ${ }^{[5]}$ Endometrioma can be discussed as a syndrome complex of Udavartini Yonivyapad in Ayurveda. Hence Acharya Charaka explains that Vata gets aggravated due to Vega dharana and moves in reverse direction, then settles in yoni and produces the pain, initially pushes raja in upward direction, then discharges it with difficulty. The woman feels relief immediately after the discharge of menstrual blood. Since in this condition the raja moves upward direction, it is termed as Udavartini ${ }^{[6]}$ thus Vyadhisankara can be helpful in prognosis and planning treatment protocol for endometriosis (Udavarthini Yonivyapad). Vyadhisankara can happen due to Nidanarthakaratwa or as a result of Upadrava differentiating these two concepts gives clarity in planning right treatment strategies. ${ }^{[7]}$

Here an effort was made to treat endometriotic cysts. This case is an ideal example of ovarian endometrioma, and is successfully treated with Ayurveda protocol under the auspices of Vyadhisankara concept.

\section{Case report:}

A 32-year-old unmarried woman consulted the BMARI hospital with a chief complaint of sever lower abdominal pain, severe menstrual pain and prolong bleeding since 5 years duration. Her bowel and bladder habit were normal and surgical history of laparoscopic cystectomy in right side endometrioma (chocolate cyst) on 2017. No other significant surgical history was obtained. On general examination, she was found to be average built and weighing $62 \mathrm{~kg}$. On bimanual pelvic examination, severe tenderness was detected around the right ovarian side. Laboratory tests were unremarkable except that the Tumor marker. CA - 125 value- 41.1U/ML

Radiological ultrasound revealed (Abdominal Ultrasonography) bulky uterus with adenomyosis. The right endometriotic cysts/ endometrioma were seen which were thin walled with diffuse homogeneous groundglass echoes contents measuring around of $3.72 \mathrm{~cm} \times 1.84 \mathrm{~cm}$ in size in the right ovary and $3.09 \mathrm{~cm} \mathrm{x} 2.22 \mathrm{~cm}$ in left ovary; in 
addition, highly echogenic peritoneal fluid in the cul-de-sac and a pre-ovulatory follicle in the left ovary were observed. The treatment was Amapachana (digestion of undigested food), Agnideepana (increase digestive fire), Srotosodhaka (clear channel) and Vata Anulomana(downward movement of Vata). The sequence of treatment was as follows:

Preparatory therapy: The initial treatment with:

\section{Panchamuli Lagu Drakshadi Kwatha $30 \mathrm{ml} /$ two times a day}

2. Chirabilvadi Kwatha $30 \mathrm{ml} /$ two times a day

3. Krimigathani pills $2 /$ two times a day

4. Manibadra Choorana $5 \mathrm{~g} / \mathrm{two}$ times a day for 15 days were administrated to regularize the appetite and bowel movement. Agni Vishamya (Aama) is main root cause of all disease. Hence the medication should focus on Agni Deepana Aama Pachana Vata Anulomana.

The treatment schedule given to the patient was as per given below Table 1

Table-1: Timeline of case study

\begin{tabular}{|c|l|}
\hline Date and Year & \multicolumn{1}{|c|}{ Clinical events and Intervention } \\
\hline 08 January 2020 & $\begin{array}{l}\text { Patient came to OPD with complains of - Pain in lower abdomen, } \\
\text { sever menstrual pain, and prolong bleeding. LMP was - /09/01/2020 } \\
\text { Day 12 Trans abdominal USG was advised. } \\
\text { Initial treatment with } \\
\text { Panchamuli Lagu Drakshadi Kwatha 30ml / two times a day } \\
\text { Chirabilvadi Kwatha 30 ml / two times a day } \\
\text { Krimigathani pills 2 two times a day } \\
\text { Manibadra Choorana 5g / two times a day were administered. }\end{array}$ \\
\hline 12 January 2020 & $\begin{array}{l}\text { Trans abdominal USG was done. USG findings showed- right ovary } \\
\text { Chocolate cyst measuring 3.72 X 1.84 cm and 3.09cm x 2.22 cm size } \\
\text { in Left ovary. } \\
\text { Bulky uterus with adenomyosis }\end{array}$ \\
\hline 20 January 2020 & $\begin{array}{l}\text { Patient was admitted to IPD unit of Stree Roga \& Prasuti Tantra. } \\
\text { On the basis on USG finding } \\
\text { Main Therapy } \\
\text { drug and procedures were advised to continue as below } \\
\text { Panchakarma procedures \& oral drugs }\end{array}$ \\
& \\
\hline
\end{tabular}


INTERNATIONAL JOURNAL OF AYUSH CASE REPORTS (IJA-CARE)

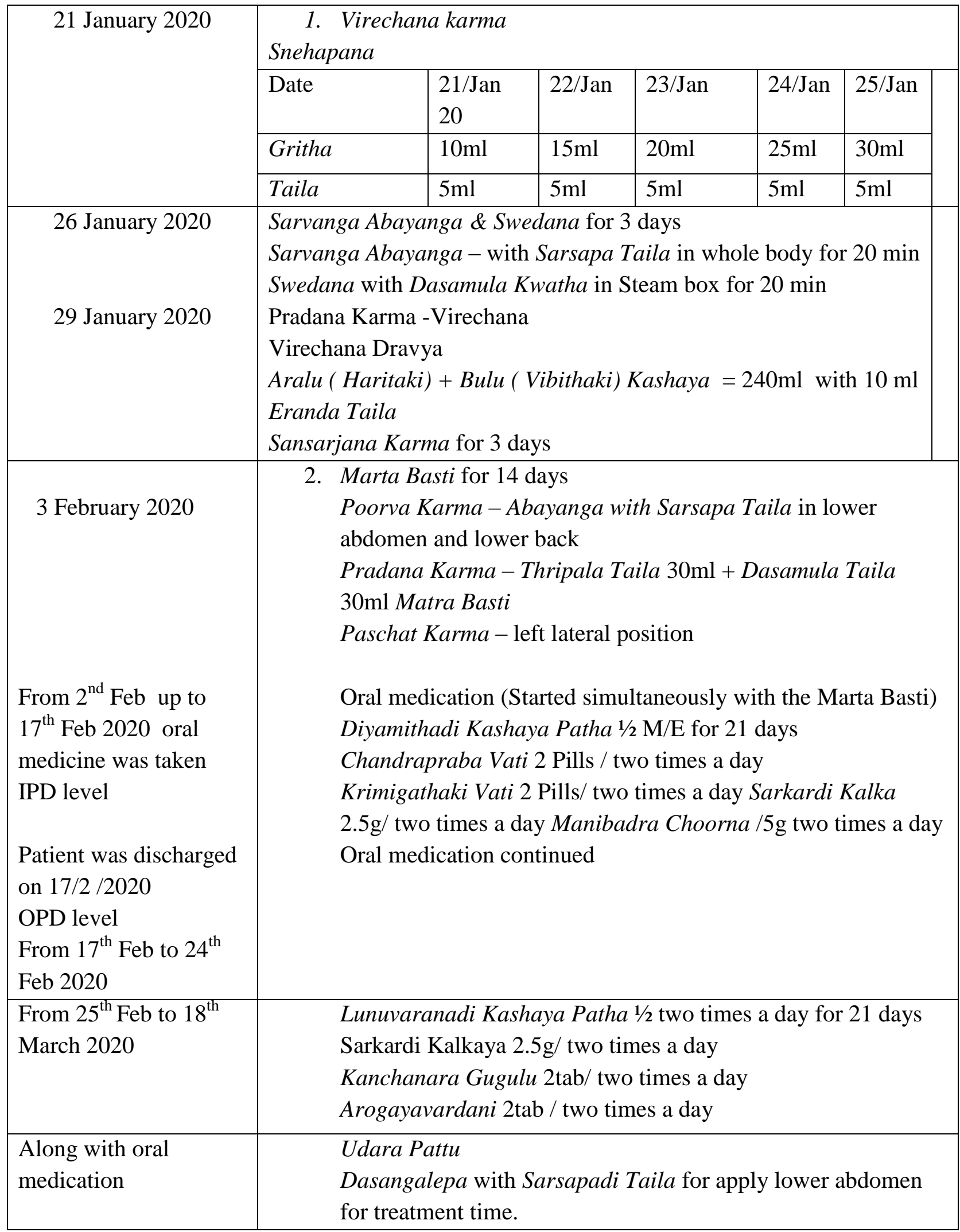



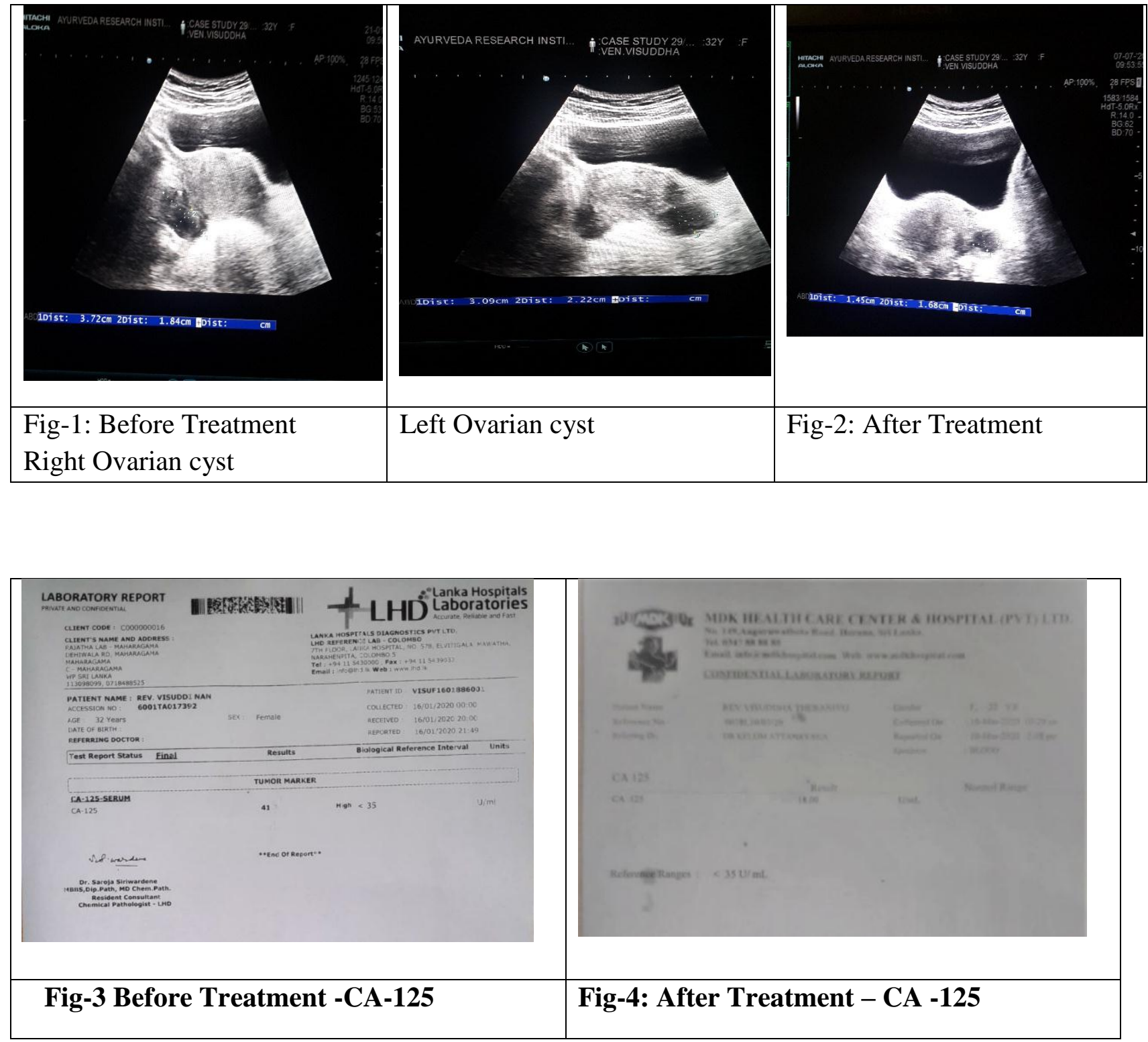

Duration of Treatment: The total treatment duration was 10 weeks. Diet \& Behavioural Changes advised. The patient had follow-up for one year after the cessation of Ayurveda medicine.

\section{Result:}

Patient recovered completely from pain lower abdomen, Menstrual cycle was regular and at normal intervals without any complications.
After treatment CA-125 tumour marker value - 16 U/ML (Copy Attached) \& USG revealed normal study.

The preparatory therapy began 08-01.2020 and the patient was advised to have Ultrasonography after 70 days of treatment. The USG study dated 08-01-2020 found the endometrioma in right ovary to be $3.72 \mathrm{~cm}$ $\mathrm{x} 1.84 \mathrm{~cm}$ and $3.09 \mathrm{~cm} \times 2.22 \mathrm{~cm}$ on left ovary. After treatment and follow up period another 
revealed normal findings with right ovary and left ovary cyst reduced and size to be $1.45 \mathrm{~cm} \times 1.68 \mathrm{~cm}$. This patient has no relapse/recurrence of the ovarian cyst after Ayurveda treatment. Before and after USG images are given in Figure 1 and 2 . Completely disappear on right ovarian cyst and Left ovarian cyst size reduced from 3.09 $\mathrm{cm} \mathrm{x} 2.22 \mathrm{~cm}$ to $1.45 \mathrm{~cm} \times 1.65 \mathrm{~cm}$

\section{Discussion:}

The case was treated on the line of management of Udavartani Yonivyapad with special concentration to Vyadhisankara. Primary disease exists with secondary disease subsequently condition is known as Vyadhisankara. Hence Udavartani is primary disease therefore mainly Vata Anulomana drugs were prescribed due to Prathilomagathi of Vata (upward movement of Vata) while separate line of treatment for kapha pacifying properties were planned for the condition of kaphaja Granthi (endometrioma) as secondary disease. Udavartani (Endometriosis) is a condition Vitiation of the Apana and Vyana Vata, results in retrograde flow of menstruation, lymphatic and vascular spread of endometrial tissues. The ectopic implants of endometrium may get enlarged with subsequent menstrual cycles. Adhesions develop with association of Kapha Dosha. Therefore, treatment focused on Agni Deepana Aama Pachana with Shodhana in order to remove the Aama and get the Doshas back into original locations and Vatasamana with due consideration to associated Kapha Dosha by Lekhaniya Dravyas. This shows that if plan of treatment is selected according to principles of Ayurveda along with proper drug, dose, duration, Anupana, Pathya and Apathya there is assertion of progress in treatment.

\section{Conclusion:}

Hence it is concluded that above treatment protocol is effective in the management of Udavartini Yoni Vyapad with Kaphajagranthi (Endometriosis with Ovarian Endometrioma).

\section{Consent of patient:}

The written consent has been taken from patient before the procedure as well as to publish the case report without exploring identity of the patient.

\section{Limitation of study:}

Difficulty in summarizing case study into general studies therefore most useful in the first phase of research process.

\section{Acknowledgements:}

Dr (Mrs) Wasantha Weerapana in charge and staff of ward no 04 Dr (Mrs) Swarna Kaluthota Director of Bandaranayake Memorial Ayurved Research Institute, Navinna, Maharagama, Sri Lanka, Commissioner of Ayurveda, Department of Ayurveda, Navinna, Maharagama, Sri Lanka. 


\section{References:}

1. Nisolle M, Donnez J. Peritoneal endometriosis, ovarian endometriosis, and adenomyotic nodules of the rectovaginal septum are three different entities. Fertil Steril. 1997; Oct 68 (4) 585-596.

2. Brosens IA, Puttemans PJ, Deprest J. The endoscopic localization of endometrial implants in the ovarian chocolate cyst. Fertil Steril. Pubmed 1994; June 61 (6):1034-1038.

3. Shastri AD, editors Sushrut Samhita, Granthi-Apachi-Arbud-Galganda Nidana Adhyaya. 15/1 reprint Chaukhamba Sanskrit Sansthan Varanasi (India); 2016. p. 311.

4. Gupta AD, editors Astang Samgraha. Uttara Tantra, GranthiArbud-Shlipada-Apachi-Nadi Vijananiya Adhyaya 34/3. Reprint. Chaukhambha Krishnadas Academy Varanasi (India); 2016. p. 803-804.

5. Tripathy BN, editors. Astanga Hridaya. Chikitsa Sthana, Uttara Sthana, GranthiArbud-Shlipada-Apachi-Nadi Vijananiya Adhyaya.29/1 Reprint. Chaukhambha
Sanskrit Pratisthan Delhi (India); 2012. p. 881.

6. Pandey K, Chaturvedi G, editors. Charaka Samhita, Chikitsa sthana, Shwayathu Chikitsaadhyaya.12/74 $\quad-81$ Reprint. Chaukhambha Bharati Academy Varanasi (India); 2015. p. 488

7. Tripathy B. editor Charaka Samhita, Chikitsa sthana Yoni Vyapat Chikitsa Adhyaya. 30/25-26 Vol- II, Reprint ChaukhambhaSurabharati Prakashan, Varanasi.2005.p-1014.

Conflict of interest: Author declares that there is no conflict of interest.

Guarantor: Corresponding author is guarantor of this article and its contents.

Source of support: None

How to cite this article:

Sajeewani H.L.M. G, Sajeewane Perera M.S. Ayurvedic management of Udavartini Yonivyapad (Ovarian Endometrioma)- A Case Report Int. J. AYUSH CaRe. 2020; 4(4):226-232. 